medRxiv preprint doi: https://doi.org/10.1101/2021.11.17.21266473; this version posted November 21,2021 . The copyright holder for this preprint (which was not certified by peer review) is the author/funder, who has granted medRxiv a license to display the preprint in It is made available under a CC-BY-NC-ND 4.0 International license .

\title{
ROLE OF BODY MASS AND PHYSICAL ACTIVITY IN AUTONOMIC FUNCTION MODULATION ON POST-COVID-19 CONDITION: AN OBSERVATIONAL SUBANALYSIS OF FIT-COVID STUDY
}

\section{Running title: AUTONOMIC FUNCTION MODULATION ON POST-COVID-19 CONDITION}

Ana Paula Coelho Figueira Freire ${ }^{1}$, Fabio Santos de Lira², Ana Elisa von Ah Morano², Telmo Pereira $^{3,4}$, Manuel-João Coelho Silva ${ }^{5}$, Armando Caseiro ${ }^{3,4}$, Diego Giulliano Destro Christofaro ${ }^{6}$, Osmar Marchioto Júnior ${ }^{2}$, Gilson Pires Dorneles ${ }^{7}$, Ricardo Aurino Pinho ${ }^{8}$, Bruna Spolador de Alencar Silva ${ }^{2}$

${ }^{1}$ Physiotherapy Department, Universidade do Oeste Paulista (UNOESTE), Presidente Prudente 19050-920, Brazil

${ }^{2}$ Exercise and Immunometabolism Research Group, Postgraduate Program in Movement Sciences, Department of Physical Education, Universidade Estadual Paulista (UNESP), Presidente Prudente 19060-900, Brazil

3 Polytechnic of Coimbra, ESTESC, Laboratory Biomedical Sciences, Coimbra, Portugal. Molecular Physical-Chemistry R\&D Unit, Faculty of Science and Technology, University of Coimbra, 3004-535 Coimbra, Portugal.

${ }^{4}$ Laboratory for Applied Health Research (LabinSaúde), Coimbra 3046-854, Portugal

${ }^{5}$ University of Coimbra, CIDAF, Coimbra, Portugal.

${ }^{6}$ Postgraduate Program in Movement Sciences, Department of Physical Education, Universidade Estadual Paulista (UNESP), Presidente Prudente 19060-900, Brazil

${ }^{7}$ Cellular and Molecular Immunology Lab., Universidade Federal de Ciências da Saúde de Porto Alegre, Porto Alegre, RS, Brazil.

${ }^{8}$ Graduate Program in Health Sciences, School of Medicine, Pontificia Universidade Catolica Do Parana, Curitiba 80215-901, Brazil.

\section{Corresponding author:}

Ana Paula Coelho Figueira Freire

Physiotherapy Department, Universidade do Oeste Paulista (UNOESTE), Presidente Prudente 19050-920, Brazil.

Rua José Bongiovani, 700, Presidente Prudente, São Paulo Brazil

Zip Code: 19050900 - Phone: +55 1832291000.

ORCID: https://orcid.org/0000-0002-2805-5746

NOTE: This preprint reports new research that has not been certified by peer review and should not be used to guide clinical practice. Email: anapcff@hotmail.com 
medRxiv preprint doi: https://doi.org/10.1101/2021.11.17.21266473; this version posted November 21, 2021. The copyright holder for this preprint (which was not certified by peer review) is the author/funder, who has granted medRxiv a license to display the preprint in It is made available under a CC-BY-NC-ND 4.0 International license .

\section{Key Points}

- Our main finding is that even in mild and moderate infections, young adults who had COVID-19 had greater sympathetic activity, less parasympathetic activity, and global variability when compared to uninfected individuals.

- In participants who were overweight and obese and/or physically inactive, cardiac autonomic modulation showed worse indices.

- Our study provides new insights regarding the role of body mass index and physical activity status on post-COVID-19 infection autonomic deregulation that may contribute to the understand of pathophysiology and treatment of of post-acute sequelae SARS-CoV-2 infection. 
medRxiv preprint doi: https://doi.org/10.1101/2021.11.17.21266473; this version posted November 21, 2021. The copyright holder for this preprint (which was not certified by peer review) is the author/funder, who has granted medRxiv a license to display the preprint in It is made available under a CC-BY-NC-ND 4.0 International license .

\begin{abstract}
The harmful effects of coronavirus disease 2019 (COVID-19) can reach the autonomic nervous system (ANS) and endothelial function. Therefore, the detrimental multiorgan effects of COVID19 could be induced by deregulations in ANS that may persist after the acute SARS-CoV-2 infection. Additionally, investigating the differences in ANS response in overweight/obese, and physically inactive participants who had COVID-19 compared to those who did not have the disease is necessary. The aim of the study was to analyze the autonomic function of young adults after mild-to-moderate infection with COVID-19 and to assess whether body mass index (BMI) and levels of physical activity modulates autonomic function in participants with and without COVID19. Patients previously infected with COVID-19 and healthy controls were recruited for this crosssectional observational study. A general anamnesis was taken and BMI and physical activity levels were assessed. The ANS was evaluated through heart rate variability. A total of 57 subjects were evaluated. Sympathetic nervous system activity in post-COVID-19 group was increased (stress index; $\mathrm{p}=0.0273)$. They also presented lower values of parasympathetic activity $(\mathrm{p}<0.05)$. Overweight/obese subjects in the post-COVID-19 group presented significantly lower parasympathetic activity and reduced global variability compared to non-obese in control group $(p<0.05)$. Physically inactive subjects in post-COVID-19 group presented significantly higher sympathetic activity than active subjects in control group. Parasympathetic activity was significantly increased in physically active subjects in control group compared to the physically inactive post-COVID-19 group ( $\mathrm{p}<0.05)$. COVID-19 promotes changes in the ANS of young adults, and these changes are modulated by Overweight/obesity and physical activity levels.
\end{abstract}

Keywords: COVID-19; Autonomic nervous system; Heart rate; Obesity; Exercise 
medRxiv preprint doi: https://doi.org/10.1101/2021.11.17.21266473; this version posted November 21,2021 . The copyright holder for this preprint (which was not certified by peer review) is the author/funder, who has granted medRxiv a license to display the preprint in It is made available under a CC-BY-NC-ND 4.0 International license.

\section{Introduction}

Coronavirus disease (COVID-19) is a recognized infectious disease caused by SARS-CoV-2 infection that has rapidly spread worldwide, reaching a pandemic level in 2020. COVID-19 was reported in over 170 countries and has brought unprecedented morbidity, mortality, and disruption globally. ${ }^{1,2}$ Despite severe complications that may be caused by the virus, a significantly high number of individuals did not require intensive care and continue to present sequelae months after the COVID-19 diagnosis. ${ }^{3}$

Although COVID-19 is primarily manifested as a respiratory disease, many studies have shown that it is a systemic infection involving multiple systems and affecting individuals of all ages. ${ }^{2,4}$ Initial studies showed that the harmful effects of COVID-19 could also reach the autonomic nervous system (ANS), even in non-hospitalized young individuals. Interestingly, detection of SARS-CoV-2 in carotid body of severe COVID-19 patients was previously reported, and its involvement may explain silent hypoxemia, a route of nervous system invasion and ANS deregulation. ${ }^{5-7}$ It is hypothesized that autonomic dysfunction after COVID-19 infection could be mediated by the virus itself, ${ }^{8}$ or even associated with the cytokine storm response, resulting in oxidative stress. These mediators can subsequently cross the blood-brain barrier, ultimately increasing the activation of the sympathetic nervous system (SNS). ${ }^{6,9}$ Furthermore, autonomic dysfunction has also been shown to be associated with COVID-19 severity and prognosis. ${ }^{4}$

Further investigations to clarify the impact of COVID-19 on ANS are needed since the ANS plays a major role in regulating the body's homeostasis. Any dysfunction in this system can have detrimental effects on several physiological systems, including alterations in the cardiovascular system and the immune, hematological, and renal systems. ${ }^{10}$ Additionally, a sympathetic overdrive has been identified as an independent predictor of mortality in several diseases. ${ }^{11-13}$ Koopman et al., in an epidemiological study, observed that low cardiac autonomic modulation was associated with higher chances of mortality in individuals with low cardiovascular risk. ${ }^{14}$

The autonomic imbalance may persist after acute SARS-CoV-2 infection, and the burden of several post-COVID-19 condition, including postural orthostatic tachycardia syndrome (POTS), dysautonomia, fatigue, cerebral hypoperfusion syndrome and impaired endothelial function, are associated with this condition independently of hospitalization. ${ }^{6,15,16}$ A recent clinical case study reported strong benefits of invasive vagus nerve stimulation, such as relief of chest tightness and shortness of breath, in COVID-19 patients. ${ }^{17}$ In fact, patients presenting postviral condition, such as myalgic encephalomyelitis, induced by several viruses manifest several alterations in ANS with harmful impact in the health and body homeostasis. ${ }^{18-20}$ Thus, the ANS dysfunction after acute 
medRxiv preprint doi: https://doi.org/10.1101/2021.11.17.21266473; this version posted November 21,2021 . The copyright holder for this preprint (which was not certified by peer review) is the author/funder, who has granted medRxiv a license to display the preprint in

It is made available under a CC-BY-NC-ND 4.0 International license .

SARS-CoV-2 may be not necessarily new, but an old sequela observed in several post viral infectious episodes.

It is well established that other factors can directly affect autonomic function, such as obesity $^{21,22}$ and levels of physical activity ${ }^{23,24}$. However, it is necessary to investigate if overweight and obesity can cause additional changes to the ANS after COVID-19 infection. Moreover, it is important to understand if physical activity can play a protective role on the ANS after SARS-CoV2 infection. Antagonic effects of BMI and physical activity were observed in the management of neurocognitive and fatigue symptoms, and in the incidence of post-acute sequelae SARS-CoV-2 infection (PASC) in healthcare workers. ${ }^{25}$

This information is extremely relevant to help health professionals screen patients with COVID-19 presenting additional risk factors and educate and inform the global population of the factors that can influence the clinical course of this widespread disease. Persistent symptoms and physiological alterations associated with PACS impact physical and cognitive function and healthrelated quality of life, and there is a needed to clarify the pathophysiological mechanisms of postCOVID-19 syndrome in young individuals previous infected by SARS-CoV-2 that not required acute hospitalization.

The present study adds novelty and relevant aspects to the literature since it (1) investigates cases after mild to moderate COVID-19 infection in young adults, a subgroup of patients who are often overlooked, that did not require intensive care, addressing the influence of obesity and physical activity after COVID-19 infection on the ANS (2) through the estimation of the heart rate variability (HRV), a reliable and noninvasive method. ${ }^{26}$ To our knowledge, these data are not yet available in the literature.

Thus, the primary aim of the study was to analyze the autonomic function of young adults after mild to moderate infection by COVID-19. Second, we aimed to identify the influence of body mass index (BMI) and levels of physical activity on the autonomic function in these individuals, indexed to the HRV indicators.

\section{Materials and Methods}

\section{Ethical approval}

The study was performed in accordance with ethical standards described by the Declaration of Helsinki. Additionally, all participants were informed of the study purpose and protocols and gave 
medRxiv preprint doi: https://doi.org/10.1101/2021.11.17.21266473; this version posted November 21,2021 . The copyright holder for this preprint (which was not certified by peer review) is the author/funder, who has granted medRxiv a license to display the preprint in It is made available under a CC-BY-NC-ND 4.0 International license.

written informed consent to the protocols. The Ethical Institutional Review Board approved the study (approval number: 38701820.0.0000.5402).

\section{Study design}

This is a cross-sectional observational study that is part of a broader research project: FITCOVID Study. The study was previously registered at the Brazilian Clinical Trials Registry (https://ensaiosclinicos.gov.br/) (registration number: RBR-5dqvkv3). All reports followed the Strengthening the Reporting of Observational Studies in Epidemiology (STROBE) guidelines. ${ }^{27}$

Patients that were infected with COVID-19 were recruited to participate in the study through local media (TV, radio) and social media and via electronic access to participants' database of the Municipal Health Secretariat of Presidente Prudente São Paulo, Brazil (231,953 inhabitants; human development index, 0.806; 23,657 confirmed COVID-19 cases, moving average of 135 cases [May 2021]). Male and female patients aged 20-40 years after mild or moderate clinical COVID-19 infection (slight clinical symptoms, fever, or respiratory symptoms who were not admitted to the intensive care unit) were recruited after $<180$ days of diagnosis. ${ }^{28}$ An age-matched healthy control group that was negative for SARS-CoV-2 was also recruited. To detect confirmed or probable previous SARS-CoV-2 infection, a lateral flow test for IgM and $\mathrm{IgG}$ antibodies was conducted using internal anti-SARS-CoV-2 Immunoglobulin G (IgG) and Immunoglobulin M (IgM) ELISA kits.

The exclusion criteria were as follows: (1) presence of any chronic noncommunicable diseases, (2) smokers, (3) history of drug use, (4) medications such as anti-inflammatory drugs, antibiotics, and other known for their impact over the ANS, and (5) patients that received intensive care.

\section{Experimental measures}

\section{Initial evaluation}

A general anamnesis was taken, including sociodemographic characteristics and self-rated health and medical history (family comorbidities, cardiopulmonary symptoms, and medication use). Symptoms that emerged during acute COVID-19 infection and persistent symptoms were also evaluated. Participants were also assessed regarding their BMI and physical activity level. Finally, blood pressure after 20 minutes of rest were also performed using auscultatory blood pressure measurement. ${ }^{29}$ 
medRxiv preprint doi: https://doi.org/10.1101/2021.11.17.21266473; this version posted November 21,2021 . The copyright holder for this preprint (which was not certified by peer review) is the author/funder, who has granted medRxiv a license to display the preprint in It is made available under a CC-BY-NC-ND 4.0 International license.

According to well established methods, BMI is the ratio of weight $(\mathrm{kg})$ to height $(\mathrm{m})$ squared. To determine the weight, an electronic and previously calibrated scale (Kratos-Cas, São Paulo, SP, Brazil) was used with participants wearing light clothes, barefoot, and carrying no heavy objects. Height was determined using a portable anthropometer (Kratos-Cas, São Paulo, SP, Brazil) after accurately adjusting participant posture before reading the fixed marker. ${ }^{30}$

\section{Physical activity level}

The level of physical activity was measured using a triaxial accelerometer (GT3X+; ActiGraph, LLC, Pensacola, FL, USA). Participants were instructed to wear the accelerometer above the waist for seven consecutive days during waking hours. A minimum of four days with at least $10 \mathrm{~h}$ /day was defined as valid accelerometer data. Participants were instructed not to use the accelerometer while bathing or performing water activities. Moreover, every morning, a researcher sends a WhatsApp message reminding the participant to use the accelerometer.

Non-wear periods were defined as time intervals of at least 60 consecutive minutes of zero counts, with an activity interruption allowance of 0-100 counts/min lasting a maximum of 2 consecutive minutes. ${ }^{31}$ Counts per minute were calculated using the sum of the total activity counts in the vertical axis divided by the valid days. Sedentary time was defined as values $<100$ counts/min, light physical activity as values between 100 and 2,019 counts/min, and moderate-vigorous physical activity as values $>2,020$ counts/min. Data were processed using the ActLife software (version 6.9.2, Pensacola, FL, USA). ${ }^{32}$

\section{Heart Rate Variability}

ANS function was measured through the HRV, a simple, dependable, inexpensive, and noninvasive method..$^{26}$ For testing, participants arrived at an outpatient clinic in a fasted state, having abstained from exercise, caffeine, and alcohol for at least $24 \mathrm{~h}$ before testing and $\geq 4 \mathrm{~h}$ after a snack or light meal. Testing took place in a quiet, environmentally controlled clinic, with an ambient temperature of $\sim 23{ }^{\circ} \mathrm{C}$. Participants were asked to avoid consuming coffee, chocolate, or alcohol, taking medications the night before, and practicing vigorous physical activity $24 \mathrm{~h}$ before the assessment. HRV analysis was undertaken in the morning to avoid circadian changes. ${ }^{26}$

The heart rate was recorded beat-to-beat via a cardio-frequency meter (Polar RS800CX, Polar Electro, Kempele, Finland) at a $1 \mathrm{kHz}$ sampling rate to assess cardiac autonomic modulation. With the chest strap and monitor, individuals were placed in a sitting position and remained at rest with spontaneous breathing for $25 \mathrm{~min}$. HRV was performed on 256 consecutive intervals between successive heartbeats (RR intervals) from the most stable segment on the tachogram. Only series with $<5 \%$ error were considered suitable for analysis. Kubios HRV® software (Biosignal Analysis 
medRxiv preprint doi: https://doi.org/10.1101/2021.11.17.21266473; this version posted November 21,2021 . The copyright holder for this preprint (which was not certified by peer review) is the author/funder, who has granted medRxiv a license to display the preprint in It is made available under a CC-BY-NC-ND 4.0 International license.

and Medical Image Group, Department of Physics, University of Kuopio, Finland) was used to complete the HRV analysis. ${ }^{33,34}$

The HRV was assessed in both the time and frequency domains. For the time domain, the mean RR intervals (reflecting global variability) were used. Additionally, the following indexes were calculated:

- The square root of the mean squared difference between adjacent RR intervals (RMSSD) indicating parasympathetic modulations of the HR

- The standard deviation of all normal RR intervals (SDNN) reflecting global variability

- Geometric indexes from Poincaré plot SD1 and SD2, indicating parasympathetic and global modulations of $\mathrm{HR}$, respectively

- Triangular interpolation of normal to normal RR intervals (TINN) indicating global variability

- Triangular index (RRtri) also signifying global variability

For the frequency domain, spectral analysis was computed using the fast Fourier transform, and the following indexes were included in the study:

- The low-frequency (LF: $0.04 \mathrm{~Hz}$ to $0.15 \mathrm{~Hz}$ ) and high-frequency (HF: $0.15 \mathrm{~Hz}$ to $0.4 \mathrm{~Hz}$ ) components were computed, representing sympathetic and parasympathetic activity, respectively. The $\mathrm{LF}$ to $\mathrm{HF}(\mathrm{LF} / \mathrm{HF})$ ratio was calculated as a measure of autonomic (sympathovagal) balance.

The following indexes computed in Kubios HRV software were also included:

- Baevsky's stress index, a geometric measure of HRV reflecting cardiovascular system stress

- Parasympathetic nervous system index (PNS index), calculated based on the mean RR, RMSSD, and SD1 in normalized units

- SNS index, calculated based on the mean HR, Baevsky's stress index, and SD2 in normalized units $^{34}$

\section{Statistical analysis}

Statistical procedures were performed using GraphPad Prism (version 5.00; GraphPad Software, San Diego, CA, USA) for Windows. Data distribution was analyzed using the ShapiroWilk test. For the primary analysis of comparisons between the post COVID-19 and control groups, the unpaired t-test or Mann-Whitney $U$ test were used according to data distribution. The Fisher test was performed for categorical variables (sex). 
medRxiv preprint doi: https://doi.org/10.1101/2021.11.17.21266473; this version posted November 21,2021 . The copyright holder for this preprint (which was not certified by peer review) is the author/funder, who has granted medRxiv a license to display the preprint in

It is made available under a CC-BY-NC-ND 4.0 International license.

In our secondary analysis, the post-COVID-19 and control groups were categorized according to the BMI, dividing each group into eutrophic $\left(<25 \mathrm{~kg} / \mathrm{m}^{2}\right)$ and overweight/obese $\left(\geq 25.0 \mathrm{~kg} / \mathrm{m}^{2}\right)$. Moreover, the groups were analyzed according to levels of physical activity, considering the subjects with <150 min of Moderate to Vigorous Physical Activity (MVPA) and subjects with $\geq 150$ min of MVPA in each group. All secondary analyses were performed using the one-way analysis of variance or Kruskal-Wallis test according to data distribution. Effect sizes (ESs) were calculated for significant secondary comparisons and classified as negligible $(<0.01)$, small $(0.1-0.29)$, medium (0.3-0.49), and large (>0.5). ${ }^{35}$ Correlational analysis between the number of reported symptoms in the post-COVID-19 group and the HRV index was performed using Pearson or Spearman test according to data distribution. Independent variables that presented statistical correlation were inserted in a model of linear regression analysis. P-values $<0.05$ were considered significant.

\section{Results}

For this study, 57 subjects were evaluated. Figure 1 shows the flow diagram of the number of individuals at each stage of the study. In the post COVID-19 group, nine subjects were women, and 11 were men. In the control group, 13 subjects were men, and 5 were women.

Patients in the post-COVID-19 group were evaluated $48.45 \pm 31.41$ days after testing positive for COVID-19. These individuals were classified as mild $(\mathrm{n}=15 ; 75 \%)$ and moderate $(\mathrm{n}=5 ; 25 \%)$ cases. ${ }^{36}$ A mean of $5.75 \pm 2.61$ symptoms (clinical and respiratory) was noted. The main symptoms reported and their respective prevalence were respiratory symptoms $(\mathrm{n}=15 ; 75 \%)$, headache $(\mathrm{n}=$ $14 ; 70 \%)$, body pain $(n=14 ; 70 \%)$, anosmia $(n=10 ; 50 \%)$, ageusia $(n=9 ; 45 \%)$, fever $(n=6$; $30 \%)$, and diarrhea $(\mathrm{n}=5 ; 25 \%)$. 
medRxiv preprint doi: https://doi.org/10.1101/2021.11.17.21266473; this version posted November 21, 2021. The copyright holder for this preprint (which was not certified by peer review) is the author/funder, who has granted medRxiv a license to display the preprint in

It is made available under a CC-BY-NC-ND 4.0 International license .

Figure 1. Flow diagram of the study.

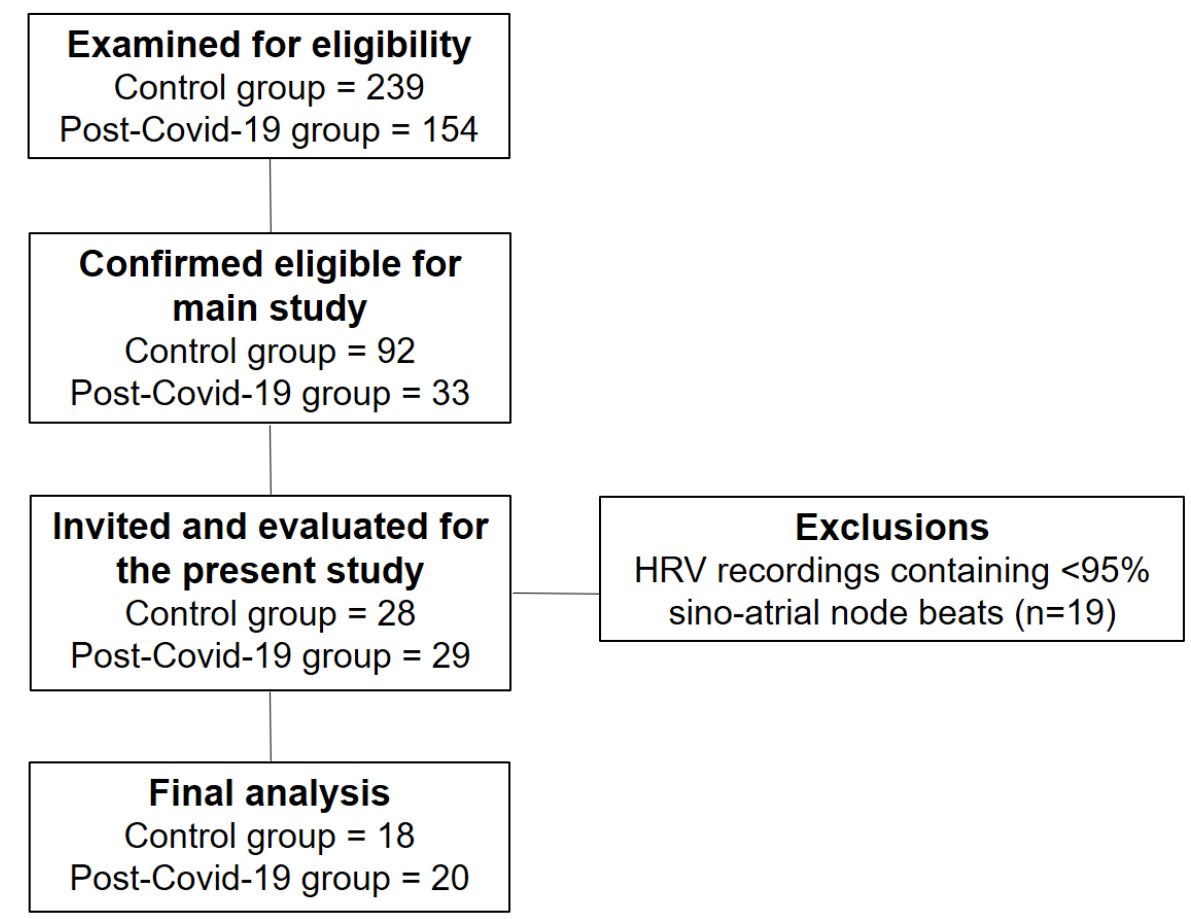

No differences in sex distribution were observed between the groups $(\mathrm{p}=0.3276)$. As indicated in Table 1, the groups were uniformly distributed $(p>0.05)$ in terms of their descriptive characteristic data, except for light physical $(\mathrm{p}=0.0444)$ and vigorous activities $(\mathrm{p}=0.0380)$. 
Table 1. Sample characterization between groups. Data with normal distribution are expressed as mean and standard deviation and data with non-normal distribution as median and $25 \%-75 \%$ interquartile range.

\begin{tabular}{lccccccc}
\hline & \multicolumn{3}{c}{ Control } & \multicolumn{3}{c}{ Post-COVID-19 } \\
\hline & Mean/median & SD/IQR & Mean/median & SD/IQR & Diff between means & 95\%CI & p-value \\
\hline Age (years) & 26.22 & 5.22 & 29.17 & 6.32 & $-2.95 \pm 1.89$ & -0.89 to 6.80 & 0.1276 \\
Weight (kg) & 74.59 & 17.32 & 76.57 & 14.36 & $-1.98 \pm 5.14$ & -8.45 to 12.42 & 0.7023 \\
BMI (kg/m²) & 24.67 & 4.79 & 26.76 & 5.12 & $-2.09 \pm 1.61$ & -1.18 to 5.36 & 0.2039 \\
Systolic blood pressure & 120.00 & {$[120-120]$} & 120,00 & {$[120-130]$} & $8.55 \pm 5.02$ & -1.64 to 18.75 & 0,1189 \\
Diastolic blood pressure & 80.00 & {$[80-80]$} & 80.00 & {$[80-80]$} & $0.05 \pm 1.06$ & -2.11 to 2.22 & 0,9588 \\
Sedentary activity (min/day) & 578.40 & {$[534.90-676.70]$} & 499.60 & {$[467.10-593.50]$} & $55.99 \pm 97.31$ & -254.70 to 142.70 & 0.5693 \\
Light activity (min/day) & 239.00 & 65.15 & 309.00 & 116.5 & $-70.01 \pm 33.37$ & 1.87 to 138.10 & $0.0444 *$ \\
Moderate activity (min/day) & 17.90 & {$[5.10-29.90]$} & 13.36 & {$[9.25-33.72]$} & $0.03 \pm 8.05$ & -16.48 to 16.41 & 0.9966 \\
Vigorous activity (min/day) & 3.64 & {$[0.0-15.80]$} & 0.00 & {$[0.00-0.50]$} & $-7.931 \pm 3.04$ & -14.14 to -1.72 & $0.0380 *$ \\
MVPA (min/day) & 23.72 & {$[12.60-46.00]$} & 14.79 & {$[9.57-34.04]$} & $8.58 \pm 9.94$ & -28.89 to 11.72 & 0.3964 \\
\hline \hline
\end{tabular}

$S D$, standard deviation; IQR, interquartile range; $k g$, kilogram; $m^{2}$, square meter; min, minutes; BMI, body mass index; MVPA, XXXXXX 
medRxiv preprint doi: https://doi.org/10.1101/2021.11.17.21266473; this version posted November 21, 2021. The copyright holder for this preprint (which was not certified by peer review) is the author/funder, who has granted medRxiv a license to display the preprint in It is made available under a CC-BY-NC-ND 4.0 International license .

Table 2 and Figure 2 illustrate the primary analysis of the study, showing intergroup comparisons between HRV indexes in the post-COVID-19 and control groups. For the SNS activity, the post-COVID-19 group showed significantly increased levels of the stress index $(\mathrm{p}=$ 0.0273).

Analysis of the parasympathetic activity showed that the post-COVID-19 group presented significant lower values of RMSSD $(\mathrm{p}=0.0452)$ and SD1 $(\mathrm{p}=0.0118)$. Additionally, participants in the post-COVID-19 group also presented lower global variability reflected through the SDNN $(\mathrm{p}=0.0282)$, TINN $(\mathrm{p}=0.0404)$, and SD2 $(\mathrm{p}=0.0145)$ indexes. 
Table 2. Comparisons between HRV indexes in the post-COVID-19 and control groups. Data with normal distribution are expressed as mean and standard deviation and data with non-normal distribution as median and 25\%-75\% interquartile range.

\begin{tabular}{|c|c|c|c|c|c|c|c|}
\hline & \multicolumn{2}{|c|}{ Control } & \multicolumn{2}{|c|}{ Post-COVID-19 } & \multirow[b]{2}{*}{$\begin{array}{c}\text { Diff between } \\
\text { means }\end{array}$} & \multirow[b]{2}{*}{$95 \% \mathrm{CI}$} & \multirow[b]{2}{*}{ p-value } \\
\hline & Mean/median & $\mathrm{SD} /[\mathbf{I Q R}]$ & Mean/median & $\mathrm{SD} /[\mathbf{I Q R}]$ & & & \\
\hline \multicolumn{8}{|c|}{ Sympathetic nervous system activity } \\
\hline Mean HR & 79.83 & 8.85 & 83.85 & 13.38 & $4.01 \pm 3.72$ & -3.54 to 11.58 & 0.2882 \\
\hline Stress index & 13.57 & 2.72 & 16.62 & 4.98 & $3.04 \pm 1.32$ & 0.35 to 5.72 & $0.0273 *$ \\
\hline LF (nu) & 65.49 & 15.30 & 66.61 & 15.65 & $1.12 \pm 5.03$ & -9.09 to 11.33 & 0.825 \\
\hline SNS index & 1.59 & 0.89 & 2.37 & 1.57 & $0.77 \pm 0.44$ & -0.07 to 1.63 & 0.0719 \\
\hline \multicolumn{8}{|c|}{ Parasympathetic nervous system activity } \\
\hline Mean RR & 738.50 & {$[694.0-846.50]$} & 689.50 & {$[648.0-800.0]$} & $-25.94 \pm 37.00$ & -101.0 to 49.15 & 0.1834 \\
\hline RMSSD & 27.40 & {$[23.40-33.15]$} & 24.45 & [14.40-28.55] & $-7.69 \pm 2.88$ & -13.55 to -1.83 & $0.0452 *$ \\
\hline HF (nu) & 34.49 & 15.30 & 33.33 & 15.65 & $-1.15 \pm 5.03$ & -11.36 to 9.05 & 0.8198 \\
\hline pNN50 & 6.73 & [3.74-12.50] & 3.41 & {$[0.25-7.36]$} & $-4.70 \pm 2.23$ & -9.24 to 0.17 & 0.055 \\
\hline $\mathrm{SD} 1(\mathrm{~ms})$ & 19.35 & [16.58-23.50] & 17.30 & [10.23-20.25] & $-5.42 \pm 2.04$ & -9.58 to -1.27 & $0.0118^{*}$ \\
\hline PNS index & -1.21 & {$[-1.49-(-0.90)]$} & -1.60 & {$[-2.13-(-0.94)]$} & $-0.36 \pm 0.23$ & -0.83 to 0.11 & 0.0845 \\
\hline \multicolumn{8}{|l|}{ Global variability } \\
\hline SDNN & 36.17 & 9.59 & 29.13 & 9.37 & $-7.04 \pm 3.07$ & -13.29 to -0.79 & $0.0282 *$ \\
\hline RR triangular index & 9.02 & 1.91 & 7.91 & 2.34 & $-1.10 \pm 0.69$ & -2.52 to 0.31 & 0.1218 \\
\hline TINN & 161.30 & 34.93 & 135 & 40.77 & $-26.33 \pm 12.39$ & -51.47 to -1.19 & $0.0404 *$ \\
\hline $\mathrm{LF} / \mathrm{HF}$ & 1.99 & [1.47-3.39] & 1.83 & [1.11-3.88] & $0.57 \pm 0.71$ & -0.86 to 2.01 & 0.9883 \\
\hline $\mathrm{SD} 2(\mathrm{~ms})$ & 47.93 & 11.53 & 38.02 & 12.17 & $-9.91 \pm 3.85$ & -17.74 to -2.08 & $0.0145^{*}$ \\
\hline
\end{tabular}

HR, heart rate; LF, low-frequency component; ms, millisecond; nu, normalized unit; SNS index, sympathetic nervous system index; RMSSD, root mean square of differences between adjacent normal RR intervals in a time interval; HF, high-frequency component; pNN50, percentage of adjacent RR intervals with a difference in duration >50 ms; SDI, standard deviation of instantaneous beat-to-beat variability; SD2, standard deviation of long-term intervals between consecutive heartbeats; PNS index, parasympathetic nervous system index; SDNN, standard deviation of all normal RR intervals recorded in a time interval; TINN, triangular interpolation of NN interval. * statistical significance ( $p<0.05$ ) between post-COVID-19 and Control group 
medRxiv preprint doi: https://doi.org/10.1101/2021.11.17.21266473; this version posted November 21, 2021. The copyright holder for this preprint (which was not certified by peer review) is the author/funder, who has granted medRxiv a license to display the preprint in

It is made available under a CC-BY-NC-ND 4.0 International license.

Figure 2. Scatterplot of HRV index comparison between the post-COVID-19 and control groups. Data are expressed as mean and standard deviation for data with normal distribution and median and 25\%-75\% interquartile range for data with non-normal distribution.
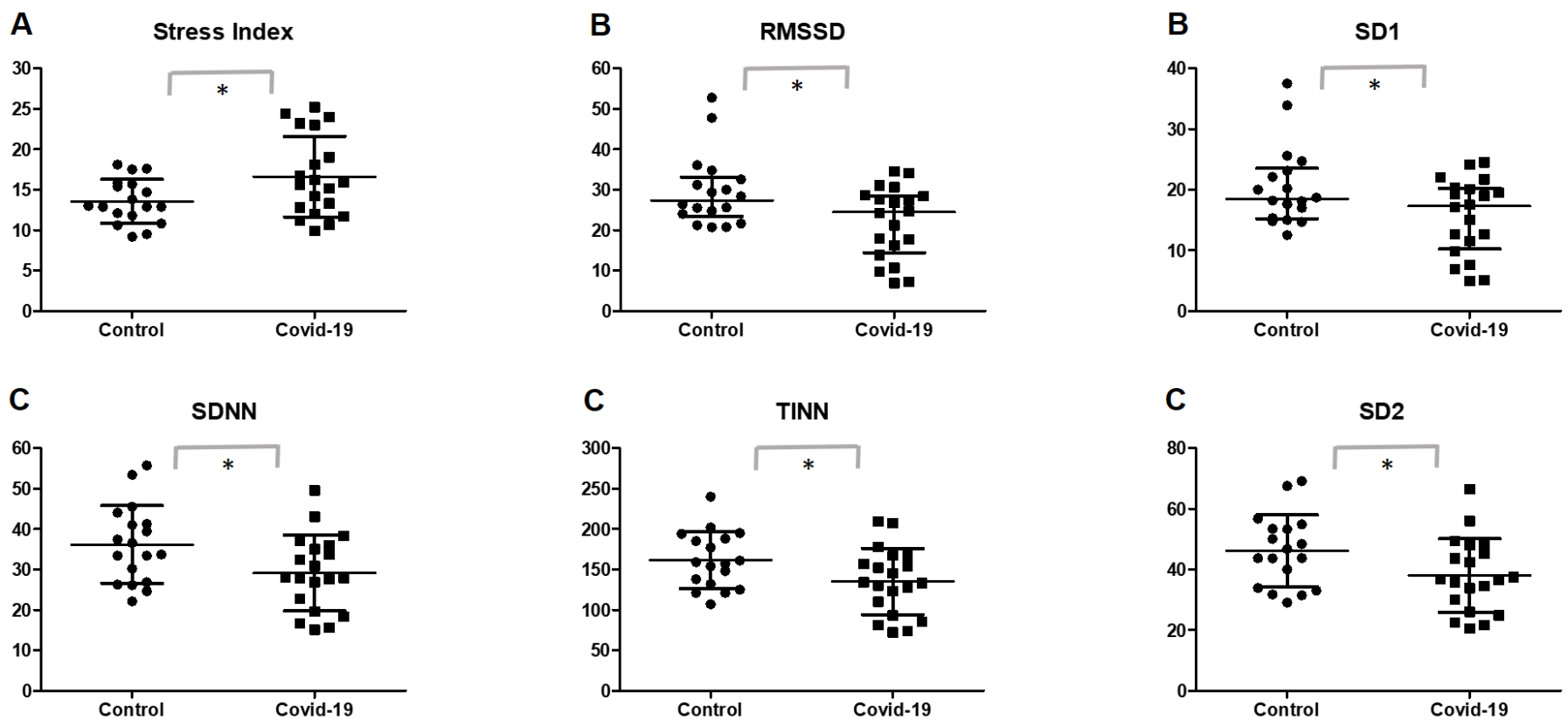

A, sympathetic nervous system activity; B, parasympathetic nervous system activity; $C$, global variability. * statistical significance $(p<0.05)$ between the post-COVID-19 and control groups; RMSSD, root mean square of differences between adjacent normal RR intervals in a time interval; SD1, standard deviation of instant beat-to-beat variability; $S D N N$, standard deviation of all normal RR intervals recorded in a time interval; TINN, triangular interpolation of NN interval; SD2, standard deviation of the long-term interval between consecutive heartbeats 
medRxiv preprint doi: https://doi.org/10.1101/2021.11.17.21266473; this version posted November 21, 2021. The copyright holder for this preprint (which was not certified by peer review) is the author/funder, who has granted medRxiv a license to display the preprint in It is made available under a CC-BY-NC-ND 4.0 International license.

In the secondary analysis, the post-COVID-19 and control groups were categorized into non-obese and overweight/obese, as shown in Table 3 and Figure 3. Overweight/obese (Ow/Ob) patients in the postCOVID-19 group presented significantly lower parasympathetic activity in the SD1 index (95\% confidence interval $[\mathrm{CI}]=-15.33$ to $-0.3959 ; \mathrm{p}=0.0301$; ES post-COVID-19 Ow/Ob vs. post-COVID19 Non-obese $=0.79$; ES post-COVID-19 Ow/Ob vs. control Ow/Ob=0.92).

Moreover, these subjects presented with reduced global variability, as shown by SDNN (95\%CI = -23.29 to $-1.453 ; \mathrm{p}=0.024$; ES post-COVID-19 Ow/Ob vs. post-COVID-19 Non-obese $=0.94$; ES postCOVID-19 Ow/Ob vs. control Ow/Ob $=0.77)$, TINN $(95 \% \mathrm{CI}=-90.41$ to $-2.826 ; \mathrm{p}=0.0288$; ES postCOVID-19 Ow/Ob vs. COVID-19 Eutro = 0.96; ES post-COVID-19 Ow/Ob vs. control Ow/Ob = 0.94), and SD2 $(95 \% \mathrm{CI}=-29.45$ to $-1.899 ; \mathrm{p}=0.0179$; ES post-COVID-19 Ow/Ob vs. post-COVID-19 Nonobese $=0.92$; ES post-COVID-19 Ow/Ob vs. control Ow/Ob = 1.03) indexes when compared with that in non-obese individuals in the control group. 
Table 3. Comparison of HRV indexes between the post-COVID-19 and control groups according to the BMI. Data with normal distribution are expressed as mean and standard deviation and data with non-normal distribution as median and 25\%-75\% interquartile range.

Control

Post-COVID-19

\begin{tabular}{|c|c|c|c|c|c|c|c|c|c|}
\hline & \multicolumn{2}{|c|}{ Non-obese } & \multicolumn{2}{|c|}{ Overweight/obese } & \multicolumn{2}{|c|}{ Non-obese } & \multicolumn{2}{|c|}{ Overweight/obese } & \multirow[b]{2}{*}{ p-value } \\
\hline & Mean/median & $\mathrm{SD} /[\mathrm{IQR}]$ & Mean/median & $\mathrm{SD} /[\mathrm{IQR}]$ & Mean/median & $\mathrm{SD} /[\mathrm{IQR}]$ & Mean/median & $\mathrm{SD} /[\mathrm{IQR}]$ & \\
\hline \multicolumn{10}{|l|}{ Sympathetic activity } \\
\hline Mean HR & 83.10 & 8.43 & 75.75 & 8.03 & 84.63 & 14.01 & 83.33 & 13.55 & 0.2421 \\
\hline Stress index & 13.70 & 3.01 & 13.41 & 2.49 & 14.59 & 3.20 & 17.97 & 5.59 & 0.2276 \\
\hline LF (nu) & 61.95 & 17.65 & 69.92 & 11.31 & 58.42 & 10.90 & 72.08 & 16.31 & 0.1643 \\
\hline SNS index & 1.82 & 0.94 & 1.29 & 0.76 & 2.09 & 1.32 & 2.55 & 1.74 & 0.2184 \\
\hline \multicolumn{10}{|c|}{ Parasympathetic activity } \\
\hline Mean RR & 728.80 & 79.83 & 800 & 90.11 & 727.50 & 141.30 & 739.2 & 131.4 & 0.2339 \\
\hline RMSSD & 28.90 & [25.58-35.13] & 24.40 & {$[21.00-32.25]$} & 26.30 & {$[18.73-33.23]$} & 21.25 & {$[9.95-27.53]$} & 0.0786 \\
\hline $\mathrm{HF}(\mathrm{nu})$ & 38.03 & 17.65 & 30.06 & 11.3 & 41.54 & 10.91 & 27.87 & 16.3 & 0.1142 \\
\hline pNN50 & 7.32 & [6.00-14.49] & 4.45 & [0.83-11.40] & 4.96 & [2.04-12.16] & 1.54 & {$[0-7.07]$} & 0.0506 \\
\hline $\mathrm{SD} 1(\mathrm{~ms})$ & 20.10 & [18.18-24.93] & 17.3 & {$[14.93-22.85]$} & 18.60 & {$[13.28-23.50]$} & 15.05 & {$[7.075-19.45]$} & $0.0301^{*}$ \\
\hline PNS index & -1.33 & {$[-1.53-(-0.92)]$} & -0.97 & {$[-1.45-(-0.82)]$} & -1.48 & {$[-2.08-(-0.95)]$} & -1.65 & {$[-2.17-(-0.71)]$} & 0.3112 \\
\hline \multicolumn{10}{|l|}{ Global variability } \\
\hline SDNN & 38.22 & 7.95 & 33.61 & 11.34 & 34.05 & 8.87 & 25.85 & 8.50 & $0.024^{*}$ \\
\hline $\mathrm{RR}$ triangular index & 9.58 & 2.26 & 8.31 & 1.12 & 9.04 & 2.04 & 7.15 & 2.29 & 0.0507 \\
\hline TINN & 167.20 & 37.96 & 154 & 31.63 & 156.60 & 36.57 & 120.60 & 38.11 & $0.0288^{*}$ \\
\hline $\mathrm{LF} / \mathrm{HF}$ & 2.06 & 1.14 & 2.91 & 1.87 & 1.58 & 0.81 & 3.97 & 3.02 & 0.0605 \\
\hline $\mathrm{SD} 2(\mathrm{~ms})$ & 49.45 & 10.61 & 46.03 & 13.06 & 44.38 & 12.20 & 33.78 & 10.6 & $0.0179^{*}$ \\
\hline
\end{tabular}

$H R$, heart rate; LF, low-frequency component; ms, millisecond; nu, normalized unit; SNS index, sympathetic nervous system index; RMSSD, root mean square of differences between adjacent normal RR intervals in a time interval; $H F$, high-frequency component; $p N N 50$, percentage of adjacent RR intervals with a difference in duration $>50$ ms; SD1, standard deviation of instantaneous beat-to-beat variability; SD2, standard deviation of long-term intervals between consecutive heartbeats; PNS index, parasympathetic nervous system index; SDNN, standard deviation of all normal RR intervals recorded in a time interval; TINN, triangular interpolation of NN interval. * statistical differences between non-obese patients in the control group and overweight/obese patients in the post-COVID-19 group. 
medRxiv preprint doi: https://doi.org/10.1101/2021.11.17.21266473; this version posted November 21, 2021. The copyright holder for this preprint (which was not certified by peer review) is the author/funder, who has granted medRxiv a license to display the preprint in

It is made available under a CC-BY-NC-ND 4.0 International license.

Figure 3. Scatterplot of HRV indexes according to the BMI Data with normal distribution are expressed as mean and standard deviation and data with non-normal distribution as median and $25 \%-75 \%$ interquartile range.
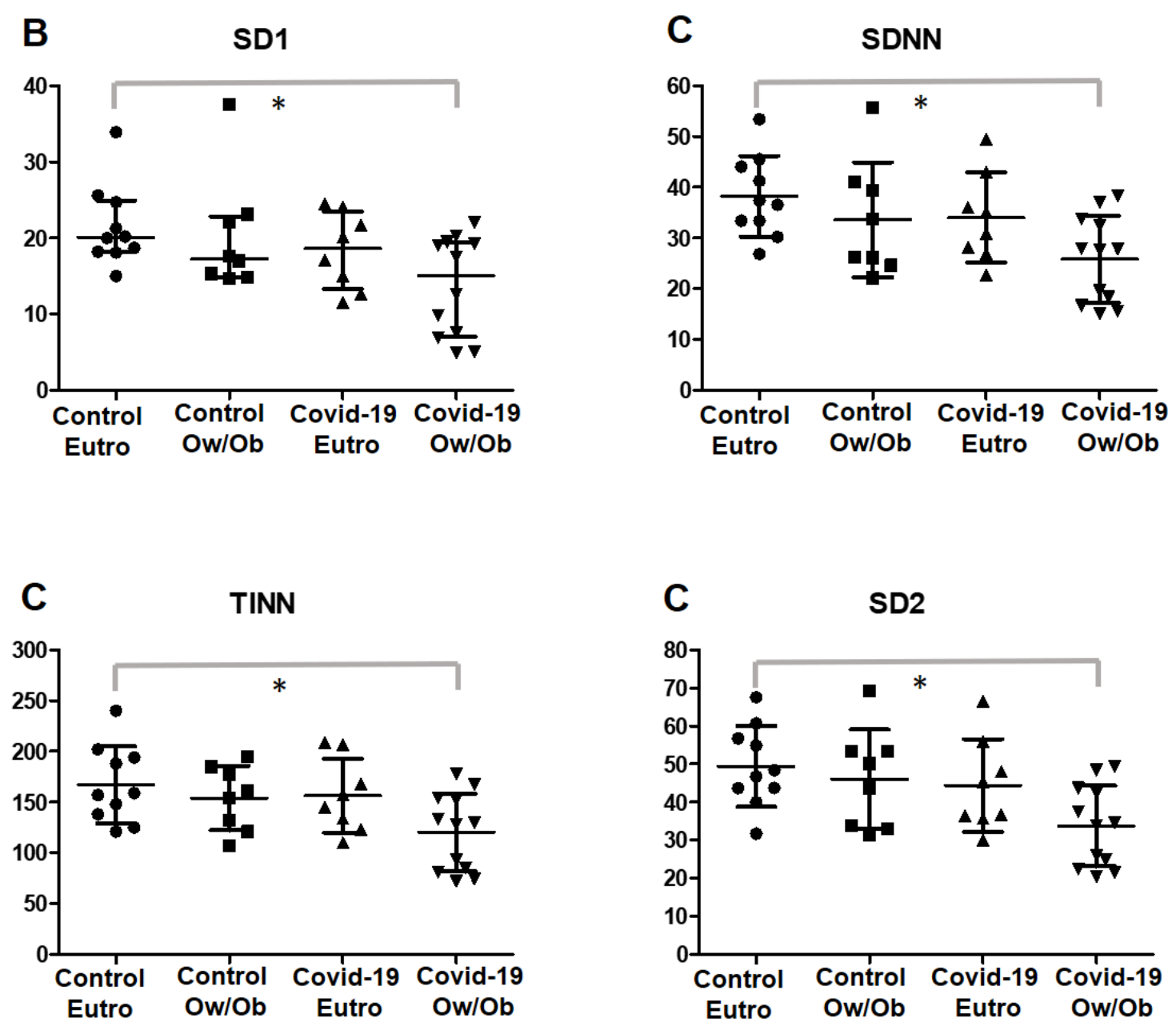

B, parasympathetic nervous system activity; $C$, global variability; *statistical differences between groups; SD1, standard deviation of instantaneous beat-to-beat variability; SDNN, standard deviation of all normal RR intervals recorded in a time interval; TINN, triangular interpolation of NN interval; SD2, standard deviation of long-term intervals between consecutive heartbeats.

Comparisons between groups were also investigated with regard to the levels of physical activity, dividing the post-COVID-19 and control groups according to the MVPA ( $\geq 150 \mathrm{~min}$ and $<150 \mathrm{~min}$ ), as shown in Table 4 and Figure 4.

Physically inactive subjects ( $<150$ min of MVPA) in the post-COVID-19 group presented with significantly higher levels of stress index compared to that in active subjects in the control group (0.0147; ES post-COVID-19 <150 min vs. post-COVID-19 $\geq 150 \mathrm{~min}=0.94$; ES post-COVID-19 $<150 \mathrm{~min}$ vs. control $<150 \mathrm{~min}=1.22$ ). PNS activity was significantly increased in physically active subjects in the control group compared to that in the physically inactive post-COVID-19 group $(<150$ min of MVPA). 
medRxiv preprint doi: https://doi.org/10.1101/2021.11.17.21266473; this version posted November 21, 2021. The copyright holder for this preprint (which was not certified by peer review) is the author/funder, who has granted medRxiv a license to display the preprint in It is made available under a CC-BY-NC-ND 4.0 International license.

These results were demonstrated through the RMSSD (ES post-COVID-19<150 min vs. postCOVID-19 $\geq 150 \mathrm{~min}=0.92$; ES post-COVID-19 <150 min vs. control <150 $\mathrm{min}=0.80)$, pNN50 (ES post-COVID-19<150 min vs. post-COVID-19 $\geq 150 \mathrm{~min}=1.16$; ES post-COVID-19<150 min vs. control $<150 \mathrm{~min}=0.71)$, and SD1 (ES post-COVID-19 $<150 \mathrm{~min}$ vs. post-COVID-19 $\geq 150 \mathrm{~min}=$ 0.92; ES post-COVID-19<150 min vs. control <150 $\min =1.00)$ indexes $(\mathrm{p}<0.05)$.

Global variability was significantly reduced in the physically inactive post-COVID-19 group $(<150$ min of MVPA) when compared with that in the physically active patients in the control group. These results can be observed in the SDNN (ES post-COVID-19 $<150$ min vs. post-COVID-19 $\geq 150 \mathrm{~min}=$ 0.83; ES post-COVID-19 <150 min vs. control <150 min = 0.69), TINN (ES post-COVID-19<150 min vs. post-COVID-19 $\geq 150 \mathrm{~min}=1.04$; ES post-COVID-19 $<150 \mathrm{~min}$ vs. control $<150 \mathrm{~min}=0.82$ ), and SD2 (ES COVID-19 <150 min vs. post-COVID-19 $\geq 150 \mathrm{~min}=0.79$; ES post-COVID-19<150 min vs. control $<150 \min =0.88)$ indexes $(\mathrm{p}<0.05)$. 
Table 4. Comparisons of HRV indexes between the post-COVID-19 and control groups according to the physical activity levels. Data with normal distribution are expressed as mean and standard deviation and data with non-normal distribution as median and $25 \%-75 \%$ interquartile range.

\begin{tabular}{|c|c|c|c|c|c|c|c|c|c|}
\hline & \multicolumn{4}{|c|}{ Control group } & \multicolumn{4}{|c|}{ Post-COVID-19 } & \multirow[b]{3}{*}{ p-value } \\
\hline & \multicolumn{2}{|c|}{$\geq 150$ min } & \multicolumn{2}{|c|}{$<150$ min } & \multicolumn{2}{|c|}{$\geq 150$ min } & \multicolumn{2}{|c|}{$<150$ min } & \\
\hline & Mean/median & SD/[IQR] & Mean/median & $\mathrm{SD} /[\mathrm{IQR}]$ & Mean/median & $\mathrm{SD} /[\mathrm{IQR}]$ & Mean/median & $\mathrm{SD} /[\mathrm{IQR}]$ & \\
\hline \multicolumn{10}{|l|}{ Sympathetic activity } \\
\hline Mean HR & 80.33 & 9.77 & 79.33 & 8.39 & 77.75 & 18.13 & 87.92 & 7.41 & 0.1755 \\
\hline Stress index & 12.90 & {$[10.70-15.20]$} & 13.80 & [12.50-16.65] & 12.40 & [11.33-14.73] & 17.40 & {$[15.68-23.15]$} & $0.0147^{*}$ \\
\hline $\mathrm{LF}(\mathrm{nu})$ & 60.08 & 18.54 & 70.91 & 9.37 & 65.20 & 13.12 & 67.56 & 17.64 & 0.5058 \\
\hline \multicolumn{10}{|c|}{ Parasympathetic activity } \\
\hline Mean RR & 757.40 & 104.10 & 763.40 & 78.92 & 806.50 & 178.10 & 686.5 & 59.63 & 0.1113 \\
\hline RMSSD & 29.40 & {$[25.95-35.45]$} & 24 & [21.00-31.90] & 28.50 & [24.33-33.33] & 17.85 & [11.48-27.15] & $0.0148^{*}$ \\
\hline $\mathrm{HF}(\mathrm{nu})$ & 39.90 & 18.54 & 29.08 & 9.37 & 34.78 & 13.11 & 32.37 & 17.63 & 0.5044 \\
\hline pNN50 & 7.84 & {$[5.76-14.85]$} & 3.95 & [0.89-10.85] & 6.48 & [4.04-12.46] & 1.45 & {$[0.0-5.82]$} & $0.0126^{*}$ \\
\hline $\mathrm{SD} 1(\mathrm{~ms})$ & 20.20 & [18.40-25.15] & 17 & [14.90-22.60] & 20.20 & [17.20-23.58] & 12.65 & [8.15-19.23] & $0.0155^{*}$ \\
\hline \multicolumn{10}{|l|}{ Global variability } \\
\hline SDNN & 39.40 & 8.40 & 32.94 & 10.07 & 33.54 & 8.14 & 26.19 & 9.27 & $0.0203 *$ \\
\hline RR triangular index & 9.52 & [8.13-10.46] & 8.45 & [6.94-8.97] & 8.92 & [8.10-10.23] & 7.65 & {$[4.97-8.40]$} & 0.0509 \\
\hline TINN & 169.40 & 26.93 & 153.20 & 41.47 & 157.90 & 35.25 & 119.80 & 38.02 & $0.0192 *$ \\
\hline $\mathrm{LF} / \mathrm{HF}$ & 1.64 & [1.06-3.30] & 2.61 & [1.64-3.43] & 1.49 & {$[1.20-3.45]$} & 2.67 & {$[0.95-4.23]$} & 0.6431 \\
\hline $\mathrm{SD} 2(\mathrm{~ms})$ & 48.40 & [43.80-58.75] & 43.70 & {$[33.45-53.35]$} & 46.65 & [37.90-49.15] & 34.25 & [25.18-37.25] & $0.0184 *$ \\
\hline
\end{tabular}

$H R$, heart rate; LF, low-frequency component; ms, millisecond; nu, normalized unit; SNS index, sympathetic nervous system index; RMSSD, root mean square of differences between adjacent normal RR intervals in a time interval; HF, high-frequency component; pNN50, percentage of adjacent RR intervals with a difference of duration >50 ms; SDI, standard deviation of instantaneous beat-to-beat variability; SD2, standard deviation of long-term intervals between consecutive heartbeats; PNS index, parasympathetic nervous system index; SDNN, standard deviation of all normal RR intervals recorded in a time interval; TINN, triangular interpolation of NN interval. * statistical significance ( $p<0.05$ ) between the control group with $\geq 150$ min of MVPA and the post-COVID-19 group with $<150$ min of MVPA. ** statistical significance ( $p<0.05)$ between the control group with 

$M V P A$ 
medRxiv preprint doi: https://doi.org/10.1101/2021.11.17.21266473; this version posted November 21, 2021. The copyright holder for this preprint (which was not certified by peer review) is the author/funder, who has granted medRxiv a license to display the preprint in

It is made available under a CC-BY-NC-ND 4.0 International license .

Figure 4. Scatterplot of HRV indexes according to the physical activity levels. Data with normal distribution are expressed as mean and standard deviation and data with non-normal distribution as median and $25 \%-75 \%$ interquartile range.
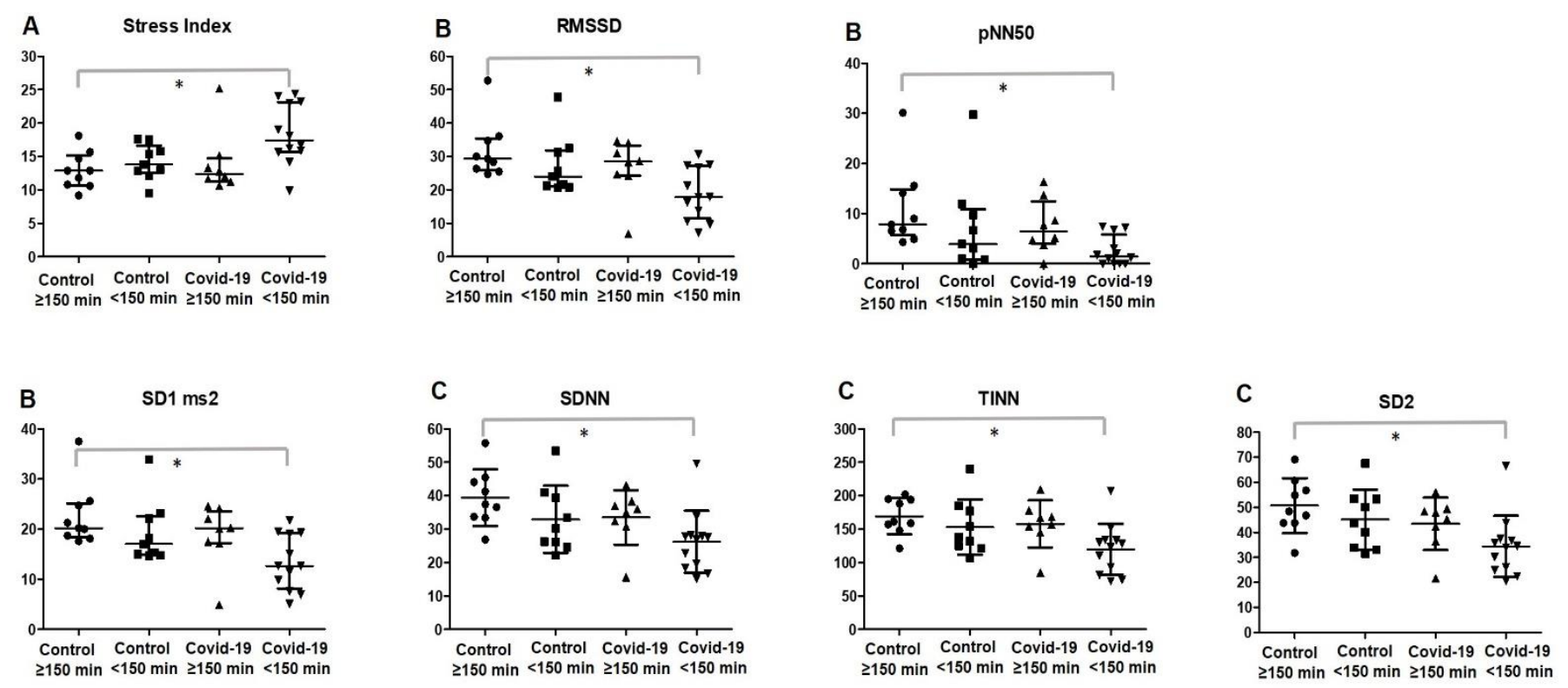

$A$, sympathetic nervous system activity; $B$, parasympathetic nervous system activity; $C$, global variability. * statistical significance $(p<0.05)$ between the control group with $\geq 150$ min of MVPA and the COVID-19 group with $<150$ min of MVPA. RMSSD, root mean square of differences between adjacent normal RR intervals in a time interval; pNN50, percentage of adjacent RR intervals with a difference of duration >50 ms; SD1, standard deviation of instantaneous beat-to-beat variability; SD2, standard deviation of long-term intervals between consecutive heartbeats; SDNN, standard deviation of all normal RR intervals recorded in a time interval; TINN, triangular interpolation of $N N$ interval

Additionally, the combination of overweight/obesity and low levels of physical activity was investigated to determine if it could impact the ANS in non-obese and physically active individuals, as shown in Table 5. Identified participants who were overweight/obese with an MVPA $<150$ min in the post-COVID-19 group presented significantly higher values of sympathetic activity $(p=0.0149)$ compared with that in eutrophic participants with an MVPA >150 min in the control group.

Furthermore, parasympathetic activity and global variability are notably reduced in participants who were overweight/obese with an MVPA $<150 \mathrm{~min}$ in the post-COVID-19 group. 
Table 5. Comparison of HRV indexes between eutrophic and physically active subjects that presented with both overweight/obesity status and low levels of physical activity in both groups. Data are expressed as median and $25 \%-75 \%$ interquartile range.

\begin{tabular}{|c|c|c|c|c|c|c|c|c|c|}
\hline & \multicolumn{4}{|c|}{ Control } & \multicolumn{5}{|c|}{ Post-COVID-19 } \\
\hline & \multicolumn{2}{|c|}{ Non-obese + >150-min MVPA } & \multicolumn{2}{|c|}{ Ow/Ob + <150-min MVPA } & \multicolumn{2}{|c|}{ Non-obese + >150-min MVPA } & \multicolumn{2}{|c|}{ Ow/Ob + <150-min MVPA } & \multirow[b]{2}{*}{ p-value } \\
\hline & Mean/median & $\mathrm{SD} /[\mathrm{IQR}]$ & Mean/median & $\mathrm{SD} /[\mathrm{IQR}]$ & Mean/median & $\mathrm{SD} /[\mathrm{IQR}]$ & Mean/median & $\mathrm{SD} /[\mathrm{IQR}]$ & \\
\hline \multicolumn{10}{|l|}{ Sympathetic activity } \\
\hline Mean HR & 84 & {$[75-87.00]$} & 77.5 & {$[70.75-81.00]$} & 84.5 & [63.50-94.25] & 90 & {$[82.50-91.00]$} & 0.0772 \\
\hline Stress index & 12.9 & {$[10.80-15.70]$} & 13.4 & {$[12.70-16.25]$} & 13.05 & [ 11.98-14.73] & 19.6 & {$[15.68-23.80]$} & $0.0149 *$ \\
\hline $\mathrm{LF}(\mathrm{nu})$ & 62.13 & [41.57-72.84] & 67.55 & {$[60.43-80.16]$} & 55.19 & {$[51.51-58.73]$} & 78.63 & {$[48.76-86.92]$} & 0.2434 \\
\hline SNS index & 1.55 & {$[0.92-2.52]$} & 1.365 & [1.14-1.92] & 1.68 & {$[0.41-2.71]$} & 3.11 & {$[2.05-4.00]$} & $0.0237 * *$ \\
\hline \multicolumn{10}{|c|}{ Parasympathetic activity } \\
\hline Mean RR & 716 & [688.0-795.0] & 772.5 & {$[744.0-847.3]$} & 712 & [636.0-958.3] & 668.5 & {$[658.0-727.0]$} & 0.0659 \\
\hline RMSSD & 29.4 & [26.4-34.80] & 22.8 & [20.78-31.55] & 31.25 & {$[25.25-34.48]$} & 15.8 & $9.95-27.15$ & $0.0174 *$ \\
\hline $\mathrm{HF}(\mathrm{nu})$ & 37.89 & [27.14-58.37] & 32.44 & [19.82-39.55] & 44.79 & [41.23-48.48] & 21.21 & [13.06-51.18] & 0.2434 \\
\hline pNN50 & 7.84 & [6.57-14.12] & 2.475 & [0.58-10.29] & 9.47 & {$[4.83-15.70]$} & 0.5 & {$[0.0-5.60]$} & $0.0215^{*}$ \\
\hline $\mathrm{SD} 1(\mathrm{~ms})$ & 20.2 & {$[18.70-24.70]$} & 16.15 & [14.78-22.35] & 22.1 & [17.85-24.40] & 11.2 & [7.07-19.23] & $0.0174 *$ \\
\hline PNS index & -1.32 & {$[-1.410-(-0.98)]$} & -0.975 & {$[-1.41-(-0.90)]$} & -1.275 & {$[-1.798-(-0.025)]$} & -1.825 & {$[-2.17-(-1.33)]$} & 0.5407 \\
\hline \multicolumn{10}{|l|}{ Global variability } \\
\hline SDNN & 37.4 & [33.40-44.10] & 26.2 & [23.98-39.80] & 35.5 & [31.93-41.33] & 23.6 & [17.13-27.88] & $0.0128 *$ \\
\hline RR triangular index & 9.52 & {$[8.0-11.06]$} & 8.09 & [6.78-8.89] & 8.92 & [8.76-11.38] & 6.81 & {$[4.51-8.40]$} & $0.0374 *$ \\
\hline TINN & 159 & [148.0-194.0] & 143 & [117.5-179.0] & 162.5 & [148.0-198.8] & 110.5 & [75.75-132.3] & $0.0123^{*}$ \\
\hline $\mathrm{LF} / \mathrm{HF}$ & 1.641 & {$[0.71-2.68]$} & 2.15 & [1.53-4.31] & 1.23 & [1.06-1.42] & 3.703 & {$[0.95-7.06]$} & 0.2434 \\
\hline $\mathrm{SD} 2(\mathrm{~ms})$ & 48.4 & [43.80-56.80] & 42 & [32.63-53.33] & 46.65 & {$[1.67-2.68]$} & 29.95 & [23.10] & 0.0198* \\
\hline
\end{tabular}

HR, heart rate; LF, low-frequency component; ms, millisecond; nu, normalized unit; SNS index, sympathetic nervous system index; RMSSD, root mean square of differences between adjacent normal RR intervals in a time interval; HF, high-frequency component; pNN50, percentage of adjacent RR intervals with a difference of duration >50 ms; SDI, standard deviation of instantaneous beat-to-beat variability; SD2, standard deviation of long-term intervals between consecutive heartbeats; PNS index, parasympathetic nervous system index; $S D N N$, standard deviation of all normal RR intervals recorded in a time interval; TINN, triangular interpolation of NN interval. * statistical significance ( $p<0.05$ ) between non-obese patients with >150-min MVPA in the control group and overweight/obese patients with <150-min MVPA in the post-COVID-19 group.** statistical significance ( $p<0.05)$ between overweight/obese patients with <150-min MVPA in the control group and overweight/obese patients with <150-min MVPA in the post-COVID-19 group 
medRxiv preprint doi: https://doi.org/10.1101/2021.11.17.21266473; this version posted November 21,2021 . The copyright holder for this preprint (which was not certified by peer review) is the author/funder, who has granted medRxiv a license to display the preprint in

It is made available under a CC-BY-NC-ND 4.0 International license.

Correlations were also evaluated, and a linear regression was performed between the numbers of symptoms reported by patients during the course of the COVID-19 infection and HRV indexes. In these analyses, significant results were identified for $\mathrm{LF}\left(\beta=0.075 ; 95 \% \mathrm{CI}=0.002\right.$ to $0.14 ; \mathrm{r}^{2}=0.20$; $\mathrm{p}=0.046) ; \mathrm{HF}\left(\beta=0.075 ; 95 \% \mathrm{CI}=-0.149\right.$ to $\left.-0.002 ; \mathrm{r}^{2}=0.204 ; \mathrm{p}=0.046\right)$, and $\mathrm{LF} / \mathrm{HF}$ components in normalized units $\left(\beta=0.48 ; 95 \% \mathrm{CI}=0.052\right.$ to $\left.0.90, \mathrm{r}^{2}=0.23 ; \mathrm{p}=0.030\right)$.

\section{Discussion}

This study analyzed if COVID-19 may affect the autonomic function of young adults after mild and moderate infections. The relationship between BMI and physical activity level with autonomic function was also investigated. Our main finding is that even in mild and moderate infections, young adults who had COVID-19 had greater sympathetic activity, less parasympathetic activity, and global variability when compared to that in uninfected individuals. Moreover, in participants who were overweight and obese and/or physically inactive, cardiac autonomic modulation showed worse indices. Collectively, our study provides new insights regarding the role of BMI and physical activity status on post-COVID-19 infection autonomic deregulation that may contribute to the understand of pathophysiology and treatment of PACS.

Corroborating our findings, a recent study by Stute et al. $(2021)^{5}$ also showed that young adults recovering from COVID-19 presented with autonomic dysregulation. The study used an invasive method (muscle sympathetic nerve activity) in 16 subjects after COVID-19 infection, which contrasts with our study that showed similar results through HRV analysis, a simple, dependable, inexpensive, and noninvasive method. ${ }^{26}$ Using wearable sensor data, Radin and colleagues ${ }^{37}$ reported a prolonged physiological impact of SARS-CoV-2 infection, lasting approximately 2-3 months, on resting heart rate which may reflet ANS dysfunction.

The prolonged alterations in autonomic function may be related to a persistent systemic inflammatory condition observed in post-viral stage. These findings may be attributed to the increased state of inflammation generated during COVID-19 infection, as well as the direct infusion of inflammatory cytokines. ${ }^{8,9}$ These mechanisms are often characterized by marked increases in SNS activity. ${ }^{5,38}$ The presence of markers of oxidative stress in COVID-19 and other viral diseases has been observed. ${ }^{8,39}$ Therefore, we believe that the oxidative stress and subsequent release of inflammatory cytokines that accompany SARS-CoV-2 infection could explain the alterations in the ANS in young subjects after COVID-19 in our study. Other factors explaining ANS alterations may also be attributed to behavioral changes during and after infection, such as changes in physical activity, ${ }^{40}$ nutritional status, ${ }^{41}$ and food and fluid consumption. ${ }^{42}$ These conditions also affect the blood volume (causing hypovolemia) and cardiovascular response. ${ }^{5}$ 
medRxiv preprint doi: https://doi.org/10.1101/2021.11.17.21266473; this version posted November 21,2021 . The copyright holder for this preprint (which was not certified by peer review) is the author/funder, who has granted medRxiv a license to display the preprint in It is made available under a CC-BY-NC-ND 4.0 International license.

This result highlights the urgency of assessments regarding the progression of COVID-19 in patients who have recovered, even if they are young or had mild or moderate symptoms since an ANS dysregulation reveals a body homeostasis dysfunction and can predict cardiovascular and metabolic illnesses and are directly correlated with mortality in several diseases. ${ }^{10,43}$

It is known that COVID-19 can affect different organs and systems at different magnitudes. ${ }^{6,38}$ However, the impact of COVID-19 on the autonomic function of young individuals and its relationship with the BMI and physical activity level are not yet well established. Our findings revealed that patients who were overweight/obese in the post-COVID-19 group presented significantly lower parasympathetic activity and reduced global variability compared to that in eutrophic individuals in the control group (Table 3 and Figure 3). Autonomic dysfunction after COVID-19 can be aggravated in individuals with obesity since studies previously showed that reduced HRV is associated with obesity and inflammation. ${ }^{44}$ The chronic low-grade inflammation caused by obesity, ${ }^{45}$ combined with the cytokine storm response from the COVID-19 infection, ${ }^{9}$ may promote an even worse autonomic dysregulation in overweight/obese patients.

Our study showed that in physically active participants, cardiac autonomic modulation levels were better when compared to that in their inactive peers, even in participants who had COVID-19. These findings corroborate with substantial data showing that exercise promotes positive adaptations in HRV parameters in both control subjects and patients suffering from a variety of diseases. ${ }^{23,43}$ Similarly, both exercise training and physical activity habits improves heart rate variability parameters, the autonomic profile, arterial compliance as well as the baroreflex sensitivity in HIV+ patients, highlighting the impact of lifestyle habits to modulate ANS in viral conditions. ${ }^{46,47}$

Regular exercise can promote functional and structural changes in the central and peripheral mechanisms of the cardiovascular system to ensure proper blood perfusion and cardiac response according to metabolic demands. ${ }^{48}$ There is a consistent body of evidence stating that exercise increases resting vagal activity and induces neuronal plasticity in central autonomic networks. It is suggested that these mechanisms are mainly related to improved control of the nucleus tractus solitarii, rostral ventrolateral medulla, and paraventricular nucleus of the hypothalamus. ${ }^{48,49}$ The previous autonomic adaptations in physically active individuals may explain the protective role of exercise observed after COVID-19 infection.

Post-viral conditions, such as chronic fatigue syndrome, are characterized by autonomic dysfunction that strongly interfere in the health quality and neurocognitive aspects of the patients. Physical activity is a consistent predictor of the measure of autonomic function in chronic fatigue syndrome patients, predicting $45 \%$ of the variance in the resting HR; $36 \%$ of the variance in the sitting HR, 20\% of the variance in standing HR, 20\% of the variance in HR on tilt, and $56 \%$ of the variance in the SBP fall in phase II of the Valsalva maneuver. ${ }^{50}$ 
medRxiv preprint doi: https://doi.org/10.1101/2021.11.17.21266473; this version posted November 21,2021 . The copyright holder for this preprint (which was not certified by peer review) is the author/funder, who has granted medRxiv a license to display the preprint in It is made available under a CC-BY-NC-ND 4.0 International license .

On the other hand, associations between low levels of moderate-to-high intensity physical activity patterns with resting HR and reduced HRV was previously reported in chronic fatigue syndrome patients, suggesting that reduction in physical activity can in part be explained by autonomic dysfunction but not fatigue severity. ${ }^{51}$ Here, we reported that post COVID-19 patients had significantly low levels of vigorous physical activity that may be related to the imbalance in ANS dysfunction.

Additionally, this study revealed that the number of symptoms reported by patients during the course of the COVID-19 infection was associated with the HRV response. These data may be explained by the severity of the virus infection that will usually promote more severe symptoms, consequently affecting levels of inflammation and oxidative stress, ${ }^{3,8}$ mediating changes in the HRV. ${ }^{52}$

The main limitations to our investigation were (1) the cross-sectional nature of the study and the small sample size. This is of particular concern because our primary outcome measure (HRV) is characterized by high interindividual variability. (2) Despite matching for age and BMI, groups were not similar regarding physical activity. The post-COVID-19 group was less active, probably due to the symptoms and indisposition related to the infection, which can generate a confounding bias. Therefore, longitudinal designs monitoring healthy young subjects recovering from SARS-CoV-2 infection are undoubtedly warranted to better understand the impact of the virus on ANS activity.

This study also presents several strengths. First, young subjects with post mild and moderate COVID-19 infection were investigated, a commonly overlooked population in recent studies. Second, to our knowledge, this is the first study to investigate the influence of the BMI and physical activity level on the ANS after COVID-19. Third, our results are of great clinical relevance since it shows the importance of screening and monitoring in young adults, especially those who are overweight/obesity or physically inactive. Finally, in our study, the practice of physical activity was measured using accelerometry, which provides more reliable information about the intensity of physical activity since self-reports may be susceptible to memory bias.

As practical applications of the present study, the importance of maintaining the BMI close to eutrophic levels and the consistent practice of physical activity is highlighted, even in the time of a pandemic where social isolation may be necessary (considering all precautions, for example, when performing outdoor physical activities).

\section{Conclusions}

Mild to moderate SARS-CoV-2 infection promotes changes in the ANS of young adults that persists one month after the acute phase of the disease. Additionally, the BMI and physical activity levels modulate the changes in the ANS after COVID-19 in different perspectives: excessive BMI accentuates the changes in the ANS whilst physical activity expresses a protective effect. Finally, the 
medRxiv preprint doi: https://doi.org/10.1101/2021.11.17.21266473; this version posted November 21, 2021. The copyright holder for this preprint (which was not certified by peer review) is the author/funder, who has granted medRxiv a license to display the preprint in It is made available under a CC-BY-NC-ND 4.0 International license .

severity of the symptomatology maintained after the SARS-CoV-2 infection may also have important consequences on the daily life activities and ability to perform physical activities, thus additionally contributing to the autonomic balance of these individuals.

\section{Funding}

National Council for Scientific and Technological Development (CNPq)-Brazil and the Coordination for the Improvement of Higher Education Personnel (CAPES)-Brazil (code 001). FSL was granted a research scholarship (PQ2) from the CNPq.

\section{Acknowledgments}

We thank the National Council for Scientific and Technological Development (CNPq)-Brazil and the Coordination for the Improvement of Higher Education Personnel (CAPES)-Brazil (code 001).

\section{Data Availability Statement}

Availability of these data is open at https://data.mendeley.com/ . Freire, Ana Paula (2021), "Body mass and physical activity in autonomic function modulation on post-COVID-19 condition: an observational subanalysis of FIT-COVID study", Mendeley Data, V1, doi: 10.17632/t45r8yd6jd.1

\section{Conflicts of interests}

None of the authors has any conflicts of interests.

\section{References}

1. Atzrodt CL, Maknojia I, McCarthy RDP, Oldfield TM, Po J, Ta KTL, et al. A Guide to COVID19: a global pandemic caused by the novel coronavirus SARS-CoV-2. The FEBS journal. 2020;287(17):3633-50.

2. Ahn DG, Shin HJ, Kim MH, Lee S, Kim HS, Myoung J, et al. Current Status of Epidemiology, Diagnosis, Therapeutics, and Vaccines for Novel Coronavirus Disease 2019 (COVID-19). Journal of microbiology and biotechnology. 2020;30(3):313-24.

3. Goërtz YMJ, Van Herck M, Delbressine JM, Vaes AW, Meys R, Machado FVC, et al. Persistent symptoms 3 months after a SARS-CoV-2 infection: the post-COVID-19 syndrome? ERJ open research. 2020;6(4). 
medRxiv preprint doi: https://doi.org/10.1101/2021.11.17.21266473; this version posted November 21, 2021. The copyright holder for this preprint (which was not certified by peer review) is the author/funder, who has granted medRxiv a license to display the preprint in It is made available under a CC-BY-NC-ND 4.0 International license.

4. Pan Y, Yu Z, Yuan Y, Han J, Wang Z, Chen H, et al. Alteration of Autonomic Nervous System Is Associated With Severity and Outcomes in Patients With COVID-19. Frontiers in physiology. 2021;12:630038.

5. Stute NL, Stickford JL, Province VM, Augenreich MA, Ratchford SM, Stickford ASL. COVID19 is getting on our nerves: sympathetic neural activity and haemodynamics in young adults recovering from SARS-CoV-2. The Journal of physiology. 2021;599(18):4269-85.

6. Dani M, Dirksen A, Taraborrelli P, Torocastro M, Panagopoulos D, Sutton R, et al. Autonomic dysfunction in 'long COVID': rationale, physiology and management strategies. Clinical medicine (London, England). 2021;21(1):e63-e7.

7. Lambermont B, Davenne E, Maclot F, Delvenne P. SARS-CoV-2 in carotid body. Intensive Care Medicine. 2021;47(3):342-3.

8. Guilmot A, Maldonado Slootjes S, Sellimi A, Bronchain M, Hanseeuw B, Belkhir L, et al. Immune-mediated neurological syndromes in SARS-CoV-2-infected patients. Journal of neurology. 2021;268(3):751-7.

9. Konig MF, Powell M, Staedtke V, Bai RY, Thomas DL, Fischer N, et al. Preventing cytokine storm syndrome in COVID-19 using $\alpha-1$ adrenergic receptor antagonists. The Journal of clinical investigation. 2020;130(7):3345-7.

10. Goldberger JJ, Arora R, Buckley U, Shivkumar K. Autonomic Nervous System Dysfunction: JACC Focus Seminar. Journal of the American College of Cardiology. 2019;73(10):1189-206.

11. Brunner-La Rocca HP, Esler MD, Jennings GL, Kaye DM. Effect of cardiac sympathetic nervous activity on mode of death in congestive heart failure. European heart journal. 2001;22(13):1136-43.

12. Taylor CE, Willie CK, Ainslie PN, Tzeng YC. Assessment of human baroreflex function using carotid ultrasonography: what have we learnt? Acta physiologica (Oxford, England). 2014;211(2):297313.

13. Holwerda SW, Luehrs RE, Gremaud AL, Wooldridge NA, Stroud AK, Fiedorowicz JG, et al. Relative burst amplitude of muscle sympathetic nerve activity is an indicator of altered sympathetic outflow in chronic anxiety. Journal of neurophysiology. 2018;120(1):11-22.

14. Koopman JJ, van Bodegom D, Maan AC, Li Z, Ziem JB, Westendorp RG, et al. Heart rate variability, but not heart rate, is associated with handgrip strength and mortality in older Africans at very low cardiovascular risk: A population-based study. International journal of cardiology. 2015;187:55961.

15. Barizien N, Le Guen M, Russel S, Touche P, Huang F, Vallée A. Clinical characterization of dysautonomia in long COVID-19 patients. Scientific reports. 2021;11(1):14042. 
medRxiv preprint doi: https://doi.org/10.1101/2021.11.17.21266473; this version posted November 21,2021 . The copyright holder for this preprint (which was not certified by peer review) is the author/funder, who has granted medRxiv a license to display the preprint in It is made available under a CC-BY-NC-ND 4.0 International license.

16. Raj SR, Arnold AC, Barboi A, Claydon VE, Limberg JK, Lucci VM, et al. Long-COVID postural tachycardia syndrome: an American Autonomic Society statement. Clinical autonomic research : official journal of the Clinical Autonomic Research Society. 2021;31(3):365-8.

17. Staats P, Giannakopoulos G, Blake J, Liebler E, Levy RM. The Use of Non-invasive Vagus Nerve Stimulation to Treat Respiratory Symptoms Associated With COVID-19: A Theoretical Hypothesis and Early Clinical Experience. Neuromodulation : journal of the International Neuromodulation Society. 2020;23(6):784-8.

18. Genovesi S, Prata Pizzala DM, Pozzi M, Ratti L, Milanese M, Vincenti A, et al. Baroreceptor sensitivity and baroreceptor effectiveness index in cirrhosis: the relevance of hepatic venous pressure gradient. Liver international : official journal of the International Association for the Study of the Liver. 2010;30(2):232-9.

19. Sorkness R, Clough JJ, Castleman WL, Lemanske RF, Jr. Virus-induced airway obstruction and parasympathetic hyperresponsiveness in adult rats. American journal of respiratory and critical care medicine. 1994;150(1):28-34.

20. Freeman R, Komaroff AL. Does the chronic fatigue syndrome involve the autonomic nervous system? The American journal of medicine. 1997;102(4):357-64.

21. Williams SM, Eleftheriadou A, Alam U, Cuthbertson DJ, Wilding JPH. Cardiac Autonomic Neuropathy in Obesity, the Metabolic Syndrome and Prediabetes: A Narrative Review. Diabetes therapy : research, treatment and education of diabetes and related disorders. 2019;10(6):1995-2021.

22. Rastović M, Srdić-Galić B, Barak O, Stokić E, Polovina S. Aging, heart rate variability and metabolic impact of obesity. Acta clinica Croatica. 2019;58(3):430-8.

23. Hautala AJ, Kiviniemi AM, Tulppo MP. Individual responses to aerobic exercise: the role of the autonomic nervous system. Neuroscience and biobehavioral reviews. 2009;33(2):107-15.

24. Fu Q, Levine BD. Exercise and the autonomic nervous system. Handbook of clinical neurology. 2013;117:147-60.

25. Strahm C, Seneghini M, Güsewell S, Egger T, Leal O, Brucher A, et al. Symptoms compatible with long-COVID in healthcare workers with and without SARS-CoV-2 infection - results of a prospective multicenter cohort. medRxiv. 2021:2021.10.19.21265187.

26. Task Force of the European Society of Cardiology and the North American Society of Pacing and Electrophysiology. Heart rate variability: standards of measurement, physiological interpretation and clinical use. Circulation. 1996;93(5):1043-65.

27. von Elm E, Altman DG, Egger M, Pocock SJ, Gøtzsche PC, Vandenbroucke JP. The Strengthening the Reporting of Observational Studies in Epidemiology (STROBE) Statement: guidelines for reporting observational studies. International journal of surgery (London, England). 2014;12(12):1495-9. 
medRxiv preprint doi: https://doi.org/10.1101/2021.11.17.21266473; this version posted November 21,2021 . The copyright holder for this preprint (which was not certified by peer review) is the author/funder, who has granted medRxiv a license to display the preprint in It is made available under a CC-BY-NC-ND 4.0 International license .

28. Organization WH. COVID-19: Surveillance, case investigation and epidemiological protocols 2020 [cited 2021 July, 26]. Available from: https://www.who.int/publications/i/item/WHO-2019-nCoVSurveillance_Case_Definition-2020.2.

29. Beevers G, Lip GYH, Brien E. Blood pressure measurement. BMJ. 2001;322(7293):1043.

30. Nuttall FQ. Body Mass Index: Obesity, BMI, and Health: A Critical Review. Nutr Today. 2015;50(3):117-28.

31. Matthews CE, Chen KY, Freedson PS, Buchowski MS, Beech BM, Pate RR, et al. Amount of time spent in sedentary behaviors in the United States, 2003-2004. American journal of epidemiology. 2008;167(7):875-81.

32. Troiano RP, Berrigan D, Dodd KW, Mâsse LC, Tilert T, McDowell M. Physical activity in the United States measured by accelerometer. Medicine and science in sports and exercise. 2008;40(1):1818.

33. Vanderlei LCM, Pastre CM, Hoshi RA, Carvalho TDd, Godoy MFd. Noções básicas de variabilidade da frequência cardíaca e sua aplicabilidade clínica. Braz J Cardiovasc Surg. 2009;24(2):205-17.

34. HRV K. HRV in evaluating ANS function [cited 2021 09/25]. Available from: https://www.kubios.com/hrv-ans-function/.

35. Fritz CO, Morris PE, Richler JJ. Effect size estimates: current use, calculations, and interpretation. Journal of experimental psychology General. 2012;141(1):2-18.

36. Zhang J, Wang X, Jia X, Li J, Hu K, Chen G, et al. Risk factors for disease severity, unimprovement, and mortality in COVID-19 patients in Wuhan, China. Clinical microbiology and infection : the official publication of the European Society of Clinical Microbiology and Infectious Diseases. 2020;26(6):767-72.

37. Radin JM, Quer G, Ramos E, Baca-Motes K, Gadaleta M, Topol EJ, et al. Assessment of Prolonged Physiological and Behavioral Changes Associated With COVID-19 Infection. JAMA Network Open. 2021;4(7):e2115959-e.

38. Porzionato A, Emmi A, Barbon S, Boscolo-Berto R, Stecco C, Stocco E, et al. Sympathetic activation: a potential link between comorbidities and COVID-19. The FEBS journal. 2020;287(17):3681-8.

39. Choi AM, Knobil K, Otterbein SL, Eastman DA, Jacoby DB. Oxidant stress responses in influenza virus pneumonia: gene expression and transcription factor activation. The American journal of physiology. 1996;271(3 Pt 1):L383-91.

40. Stockwell S, Trott M, Tully M, Shin J, Barnett Y, Butler L, et al. Changes in physical activity and sedentary behaviours from before to during the COVID-19 pandemic lockdown: a systematic review. BMJ open sport \& exercise medicine. 2021;7(1):e000960. 
medRxiv preprint doi: https://doi.org/10.1101/2021.11.17.21266473; this version posted November 21,2021 . The copyright holder for this preprint (which was not certified by peer review) is the author/funder, who has granted medRxiv a license to display the preprint in

It is made available under a CC-BY-NC-ND 4.0 International license .

41. Catucci A, Scognamiglio U, Rossi L. Lifestyle Changes Related to Eating Habits, Physical Activity, and Weight Status During COVID-19 Quarantine in Italy and Some European Countries. Frontiers in nutrition. 2021;8:718877.

42. Alamri ES. Effects of COVID-19 home confinement on eating behavior: A review. Journal of public health research. 2021;10(3).

43. Dong JG. The role of heart rate variability in sports physiology. Experimental and therapeutic medicine. 2016;11(5):1531-6.

44. Young HA, Benton D. Heart-rate variability: a biomarker to study the influence of nutrition on physiological and psychological health? Behavioural pharmacology. 2018;29(2 and 3-Spec Issue):14051.

45. Choi J, Joseph L, Pilote L. Obesity and C-reactive protein in various populations: a systematic review and meta-analysis. Obesity reviews : an official journal of the International Association for the Study of Obesity. 2013;14(3):232-44.

46. Spierer DK, DeMeersman RE, Kleinfeld J, McPherson E, Fullilove RE, Alba A, et al. Exercise training improves cardiovascular and autonomic profiles in HIV. Clinical autonomic research : official journal of the Clinical Autonomic Research Society. 2007;17(6):341-8.

47. da Silva CS, Deresz LF, Castelli GM, Dorneles GP, Mignoni L, Dal Lago P. Short-term aerobic training improves heart rate variability in men living with HIV: a pre-post pilot study. HIV research \& clinical practice. 2020;21(4):99-104.

48. da Silva VP, de Oliveira NA, Silveira H, Mello RGT, Deslandes AC. Heart rate variability indexes as a marker of chronic adaptation in athletes: a systematic review. Ann Noninvasive Electrocardiol. 2015;20(2):108-18.

49. Michelini LC, Stern JE. Exercise-induced neuronal plasticity in central autonomic networks: role in cardiovascular control. Exp Physiol. 2009;94(9):947-60.

50. Freeman R, Komaroff AL. Does the Chronic Fatigue Syndrome Involve the Autonomic Nervous System? The American journal of medicine. 1997;102(4):357-64.

51. Newton JL, Pairman J, Hallsworth K, Moore S, Plötz T, Trenell MI. Physical activity intensity but not sedentary activity is reduced in chronic fatigue syndrome and is associated with autonomic regulation. QJM : monthly journal of the Association of Physicians. 2011;104(8):681-7.

52. Del Rio R, Marcus NJ, Inestrosa NC. Potential Role of Autonomic Dysfunction in Covid-19 Morbidity and Mortality. Frontiers in physiology. 2020;11:561749. 